\title{
Kontribusi perubahan kebijakan suku bunga, jumlah anggota, dan dana pihak ketiga terhadap asset perusahaan melalui pembiayaan kredit
}

\author{
Windhu Putra ${ }^{1}$, Sri Haryaningsih ${ }^{2}$ \\ ${ }^{1}$ Universitas Tanungpura, Jl. Prof.Dr.H.Hadari Nawawi, Jendral Ahmad Yani, Pontianak Kalimantan Barat 78124, \\ Indonesia
}

\begin{tabular}{l}
\hline Article Info \\
\hline Article history: \\
Received DD xx, 202x \\
Revised DD xx, 202x \\
Accepted DD xx, 202x \\
\hline
\end{tabular}

\section{Keyword:}

Credit union

Path analysis

Data panel

\begin{abstract}
ABSTRAK
Tabungan Kopdit credit union akan menjadi sumber dana potensial untuk dapat menjadi modal kerja bagi masyarakat. Sehingga dilihat kontribusi atau peran dari Kopdit credit union dalam memperbaiki kehidupan dan mengangkat masyarakat dari jurang kemiskinan untuk menjadi lebih sejahtera. Bagaimana Kopdit credit union dapat menjadi solusi dalam mengurangi kemiskinan, dan meningkatkan kapasitas usaha kecil dan usaha mikro. Penelitian ini ingin melihat Pengaruh perubahan Kebijakan Suku Bunga, Jumlah Anggota. Metode yang digunakan pada penelitian ini adalah analis jalur (Path Analysis) dengan menggunakan data panel terhadap tiga perusahaan Credit Union (CU Khatulitiwa Bakti, CU Bona Ventura, CU Pancur Dangeri) selama 10 tahun. Dari hasil penelitian menunjukan, terjadi hubungan tidak langsung dan signifikan antara pengaruh tingkat suku bunga, jumlah anggota dan dana pihak ketiga terhadap jumlah asset melalui Pembiayaan Kredit secara simultan. Dalam pengelolaan dana pihak ketiga untuk meningkatkan asset harus melalui pembiayaan. Apabila tidak memanfaatkan instrument pembiayaan/kredit maka dikwatirkan akan menurunkan jumlah Asset.
\end{abstract}

\section{Corresponding Author:}

Haryaningsih, S.,

Universitas Tanjungpura

Email: sriharyaningsih1957@gmail.com

\section{Pendahuluan}

Perkembangan Kopdit credit union selama sepuluh tahun terakhir sangat pesat di daerah Kalimantan Barat (Beni; Beni, Rano, \& Tipo, 2017; Khosmas). Demikian juga dengan perkembangan Kopdit credit union di Indonesia berdasarkan data dari Induk Koperasi Kredit Indonesia sangat pesat sejak tahun 2009 membuat perkembangan Kopdit credit union ini menarik untuk di perhatikan. Secara kuantitas jumlah dari Kopdit credit union, justru terjadi penurunan selama periode 2009 sampai 2019 (Diskopukm, 2020).

Dilihat dari jumlah anggota, jumlah simpangan, jumlah Pembiayaan/Kredit serta kekayaan yang dimiliki terus meningkat dari tahun ke tahun. Jumlah anggota secara nasional tahun 2009 sebanyak 1.330 .581 orang, pada tahun 2019 menjadi sebanyak 3.434.109 orang (Diskopukm, 2020). Merupakan perkembangan yang sangat fantastis untuk Kopdit credit union .

Begitu juga dengan Pembiayaan/Kredit beredar, berkembang sangat pesat dari tahun 2009 sampai tahun 2019. Pinjamanan beredar tahun 2009 hanya Rp5.762.104.057.589 menjadi sebanyak Rp25.171.455.957.918 
pada tahun 2019. Pembiayaan/Kredit ini sangat menarik karena dinikmati secara langsung oleh anggota baik dalam bentuk konsumsi maupun belanja investasi dan sebagainya. Sementara itu untuk jumlah aset atau kekayaan Kopdit credit union pada tahun 2009 hanya sebanyak Rp7.396.080.394.102. Kemudian pada tahun 2019 meningkat sangat pesat menjadi sebanyak Rp. 35.242.934.041.393 (Diskopukm, 2020).

Untuk melihat perkembangan Kopdit credit union di Indonesia dapat dilihat pada Tabel 1 dari data pada Tabel 1 menunjukkan perkembangan simpanan, perkembangan pembiayaan/kredit, dan perkembangan aset dari tahun 2009 sampai dengan tahun 2019, Kopdit credit union memang luar biasa fantastis (Maran, 2021). Secara nasional seperti yang telah dikemukakan sebelumnya terdapat fenomena yang menarik. Fenomena itu tergambar dari jumlah Kopdit credit union dari tahun 2009 sampai tahun 2019 berfluktuasi dan cenderung menurun. Namun dilihat dari jumlah anggota, simpanan, Pembiayaan/Kredit beredar dan aset yang dimiliki meningkat dari tahun 2009 sampai tahun 2019. Selama periode tersebut rata-rata pertumbuhan Kopdit credit union (unit) minus $1,71 \%$, pertumbuhan anggota rata- rata $11,09 \%$, pertumbuhan simpanan $31,99 \%$, pertumbuhan Pembiayaan/Kredit beredar 30,47\% dan pertumbuhan aset sebanyak 31,23\%.

Dapat disimpulkan bahwa meskipun terjadi minus pada pertumbuhan Kopdit credit union secara keseluruhan, namun jika dilihat dari masing-masing aspek yang sudah dijabarkan sebelumnya tetap terjadi pertumbuhan yang cukup baik.

Tabel Error! No text of specified style in document. <Perkembangan Anggota, Aset, Simpanan dan Pembiayaan/Kredit Beredar Pada Koperasi Kredit Credit union Di Kalimantan Barat Dari Tahun 2000 s/d 2017 (dalam ribuan Rupiah)>

\begin{tabular}{lllll}
\hline Tahun & $\begin{array}{l}\text { Jumlah } \\
\text { Anggota }\end{array}$ & $\begin{array}{l}\text { Jumlah } \\
\text { Aset }\end{array}$ & $\begin{array}{l}\text { Jumlah } \\
\text { Simpanan }\end{array}$ & $\begin{array}{l}\text { Jumlah } \\
\text { Pinj. Beredar }\end{array}$ \\
\hline 2009 & 425.868 & 4.193 .460 .969 & 3.496 .329 .177 & 2.657 .222 .495 \\
2010 & 485.248 & 5.088 .081 .980 & 4.235 .653 .382 & 3.154 .094 .435 \\
2011 & 537.478 & 5.301 .496 .123 & 4.806 .577 .612 & 3.569 .751 .092 \\
2012 & 600.698 & 5.716 .202 .101 & 5.088 .760 .239 & 3.952 .202 .101 \\
2013 & 664.988 & 6.012 .907 .431 & 5.556 .979 .365 & 4.412 .907 .431 \\
2014 & 724.071 & 6.406 .424 .036 & 5.831 .647 .707 & 4.886 .424 .036 \\
2015 & 774.764 & 6.982 .945 .801 & 6.237 .956 .471 & 5.392 .945 .801 \\
2016 & 828.997 & 9.055 .927 .037 & 8.115 .758 .287 & 7.039 .687 .623 \\
2017 & 895.317 & 9.433 .025 .898 & 9.348 .501 .029 & 7.631 .063 .925 \\
2018 & 935.721 & 9.378 .210 .624 & 9.378 .210 .624 & 7.861 .988 .345 \\
2019 & 1.200 .764 & 9.529 .147 .913 & 9.529 .147 .913 & 8.327 .027 .086 \\
\hline
\end{tabular}

Sumber: Puskopdit BKCU Kalimantan 2020

Berdasarkan Tabel 1 diketahui Kopdit credit union di Kalimantan Barat baik dilihat dari keanggotaan, aset, simpanan dan pinjamanan beredar perkembangannya dari tahun 2009 smpai 2019 sangat pesat. Dalam kurun waktu dari tahun 2009 sampai 2019 pertumbuhan anggota rata-rata 24,89\%, pertumbuhan aset 47,04\%, pertumbuhan simpanan 46,24\% dan pertumbuhan Pembiayaan/Kredit beredar 45,13\%. Pertumbuhan yang tinggi seperti ini menggambarkan bahwa animo masyarakat dalam mengembangkan Kopdit credit union di Kalimantan Barat sangat tinggi. Dengan tingginya animo masyarakat untuk mengembangkan Kopdit credit union, berarti masyarakat merasakan adanya manfaat yang diperoleh (Hutasoit, 2019). Secara faktual perkembangan Kopdit credit union di Kalimantan Barat diikuti oleh jumlah simpanan anggota, dan jumlah Pembiayaan/Kredit beredar. Artinya anggota dapat menambah aset berupa tabungan atau simpanan dan bisa meminjam untuk meningkatkan aset sebagai manfaat yang dapat dinikmati oleh anggota dari Kopdit credit union (Hutasoit, 2019).

Kondisi lain yang menjadi perhatian dalam penelitian ini adalah keterkaitan perkembangan tabungan dengan perkembangan rata-rata tingkat bunga simpanan, dan rata-rata tingkat bunga Pembiayaan/Kredit dengan perkembangan kredit pada Kopdit credit union di Kalimantan Barat (Gustifa, 2013; F. K. Hakim \& Hasanah, 2020; L. Hakim, Sabil, Lestiningsih, \& Widodo, 2019). Perkembangan rata-rata tingkat bunga simpanan dan tingkat bunga Pembiayaan/Kredit pada Kopdit credit union di Kalimantan Barat dapat dilihat pada Tabel 2.

Dari data pada Tabel 2 dapat dilihat bahwa tingkat suku bunga simpanan pada Kopdit credit union selama 2009 sampai 2011 tidak mengalami perbuahan yaitu 15\% pertahun. Dari tahun 2012 sampai tahun 2019 suku bunga simpanan mengalami penurunan, rata-rata hanya $8,842 \%$ pertahun. Demikian juga yang terjadi dengan 
suku bunga Pembiayaan/Kredit hanya dari tahun 2009 sampai 2012 yang tidak mengalami perubahan yaitu sebesar 24\% pertahun. Kemudian dari tahun 2013 turun menjadi 18,33\% dan pada tahun 2019 sebesar 13,08\% pertahunnya (Data, 2021).

Tabel $2<$ Perkembangan Rata-rata Tingkat Bunga Simpanan dan Tingkat Bunga Pembiayaan/Kredit pada Kopdit Credit Union di Kalimantan Barat dari Tahun 2009 - 2019>

\begin{tabular}{lcc}
\hline Tahun & Bunga Simpanan & Bunga Pembiayaan/Kredit \\
\hline 2009 & 15,00 & 24,00 \\
2010 & 15,00 & 24,00 \\
2011 & 15,00 & 24,00 \\
2012 & 14,39 & 24,00 \\
2013 & 13,45 & 18,33 \\
2014 & 12,42 & 17,00 \\
2015 & 11,29 & 15,26 \\
2016 & 10,44 & 15,41 \\
2017 & 9,63 & 14,87 \\
2018 & 9,08 & 13,47 \\
2019 & 8,84 & 13,08 \\
\hline
\end{tabular}

Sumber: data olahan 2021

Suku bunga simpanan dan suku bunga Pembiayaan/Kredit yang berlaku pada Kopdit credit union dalam satu tahun, tidak mengalami perubahan, karena perubahan suku bunga harus melalui persetujuan anggota dalam rapat anggota tahunan. Proses penentuan suku bunga yang berlaku, dimulai dengan draft yang dibuat oleh pengurus, kemudian disusulkan dalam rapat anggota tahunan. Jika usulan perubahan suku bunga diterima oleh anggota yang hadir dalam rapat anggota tahunan, maka suku bunga akan berlaku untuk tahun berjalan.

Menarik untuk dikaji lebih mendalam, dimana tingkat bunga simpanan semakin menurun seperti data pada Tabel 1-3, namun disisi lain tabungan pada Kopdit credit union semakin naik. Kalau suku bunga Pembiayaan/Kredit mengindikasikan adanya hubungan yang terbalik, dimana suku bunga semakin turun seperti tanpak pada Tabel 3, sementara Pembiayaan/Kredit yang terjadi pada Kopdit credit union semakin naik seperti tampak pada Tabel 2 .

Fenomena lain terjadi pada aset Kopdit credit union di Kalimantan Ba at. Selama periode penelitian yaitu dari tahun 2009 sampai tahun 2019 aset Kopdit credit union di Kalimantan Barat selalu meningkat. Peningkatan aset dapat dilihat pada Tabel 2, dimana kecenderungannya selalu naik dari tahun ke tahun. Tabungan yang meningkat pada Kopdit credit union akan menjadi sumber dana potensial untuk dapat menjadi modal kerja bagi masyarakat (Ahmadsyah, Rahmati, \& Aufa, 2019). Sehingga dilihat kontribusi atau peran dari Kopdit credit union dalam memperbaiki kehidupan dan mengangkat masyarakat dari jurang kemiskinan untuk menjadi lebih sejahtera. Peningkatan kesejahteraan dilakukan dengan cara membangun dan mengembangkan tabungan, Pembiayaan/Kredit beredar, dan aset, meningkatkan kualitas pendidikan, serta meningkatkan pendapatan keluarga, (Sengsourivong and Mieno, 2014). Dengan demikian dapat dikatakan bahwa keberadaan Kopdit credit union merupakan satu di antara banyak solusi yang dapat digunakan untuk mengentaskan memperbaiki kondisi ekonomi di suatu negara atau daerah termasuk di Indonesia dan di Kalimantan Barat khususnya.

Bagaimana Kopdit credit union dapat menjadi solusi dalam mengurangi kemiskinan, dan meningkatkan kapasitas usaha kecil dan usaha mikro? Kopdit credit union dapat berperan dengan menyediakan Pembiayaan/Kredit sebagai modal kerja bagi individu maupun kelompok dengan skala usaha mikro, kecil dan menengah (Anam \& Khairunnisah, 2019; Ratnasari, 2014). Sehingga dapat dikatakan bahwa Kopdit credit union merupakan sebuah lembaga yang menyediakan solusi dari keterbatasan modal bagi usaha mikro kecil dan menengah.

\section{Metode}

Analisis data dilakukan dengan menggunakan analisis jalur (path analysis). Path analysis atau analisis jalur digunakan untuk menganalisis pola hubungan diantara variabel. Model ini bertujuan untuk mengetahui pengaruh langsung maupun tidak langsung seperangkat variabel bebas (eksogen) terhadap variabel (endogen). 
Koefisien jalur (path) adalah koefisien regresi yang distandarkan, yaitu koefisien regresi yang dihitung dari basis data yang telah diset dalam angka baku (Z-score). Analisis ini dibantu dengan bantuan software SPSS 16, dengan ketentuan uji $\mathrm{F}$ pada Alpha $=0,05$ atau $\mathrm{p} \leq 0,05$ sebagai taraf signifikansi $\mathrm{F}$ (sig. $\mathrm{F}$ ) sedangkan untuk uji $\mathrm{T}$ taraf signifikansi Alpha $=0,05$ atau $\mathrm{p} \leq 0,05$ yang dimunculkan kode (sig. $\mathrm{T}$ ) dimana hal tersebut digunakan untuk melihat signifikansi pengaruh tidak langsung dari variabel bebas terhadap variabel terikat. Berdasarkan tujuan penelitian yang telah ditetapkan, maka jenis penelitian ini adalah explanatory. Penelitian eksplanatori (explanatory research) adalah untuk menguji antar variabel yang dihipotesiskan. Penelitian ini terdapat 5 hipotesis yang akan diuji kebenarannya. Hipotesisi ini menggambarkan hubungan antara dua variabel, untuk mengetahui apakah variabel berasosiasi ataukah tidak dengan variabel lainnya, atau apakah variabel disebabkan atau dipengaruhi atau tidak oleh variabel lainnya. Dalam penelitian ini menggunakan model analisis jalur (path analysis) karena di antara variabel independent dengan variabel dependent terdapat mediasi yang mempengaruhi. Dalam penelitian ini terdiri lima variabel. Yakni 2 variabel bebas (independent) Suku Bunga Tabungan dan Suku Bunga Pembiayaan/Kredit, Jumlah Anggota (mediasi) sedangkan yang terikat (dependent) adalah Jumlah Asset.

\section{Hasil dan Pembahasan}

\section{Data Variabel}

Tabel 3 <Data Jumlah Pembiayaan/Kredit Anggota CU dari Tahun 2009-2019>

\begin{tabular}{lccc}
\hline Tahun & Cu Khatulitiwa Bakti & Cu Bona Ventura & Cu Pancur Dangeri \\
\hline 2009 & 90.528 .331 .425 & 47.520 .762 .892 & 27.184 .605 .550 \\
2010 & 115.410 .306 .525 & 59.936 .272 .800 & 25.875 .510 .500 \\
2011 & 155.641 .352 .675 & 79.371 .853 .300 & 27.514 .298 .916 \\
2012 & 164.785 .093 .000 & 102.203 .352 .550 & 43.707 .729 .750 \\
2013 & 261.292 .515 .575 & 124.449 .104 .450 & 53.153 .116 .230 \\
2014 & 305.709 .899 .675 & 150.114 .794 .250 & 56.580 .528 .860 \\
2015 & 370.107 .855 .879 & 167.212 .062 .550 & 62.512 .791 .300 \\
2016 & 410.147 .229 .695 & 172.722 .999 .000 & 62.061 .578 .200 \\
2017 & 411.732 .042 .942 & 175.865 .252 .300 & 63.622 .984 .500 \\
2018 & 411.556 .415 .046 & 175.818 .051 .900 & 70.869 .006 .855 \\
2019 & 439.494 .355 .349 & 166.426 .628 .300 & 73.090 .592 .245 \\
\hline
\end{tabular}

Tabel 3 menunjukkan bahwa terjadi peningkatan yang pada jumlah pembiayaan/kredit anggota CU dari tahun 2009-2018. Meskipun terjadi sedikit penurunan pada aspek cu bona ventura di tahun 2019. Dari hasil tersebut dapat disimpulkan bahwa jumlah Pembiayaan/Kredit Anggota CU dalam kurun waktu 11 tersebut secara rata-rata mengalami peningkatan.

Tabel Error! No text of specified style in document. <Data Jumlah Tabungan Anggota CU dari Tahun 2009-

2019>

\begin{tabular}{lccc}
\hline Tahun & Cu Khatulitiwa Bakti & Cu Bona Ventura & Cu Pancur Dangeri \\
\hline 2009 & 107.421 .052 .325 & 56.425 .454 .105 & $\mathbf{2 5 . 7 6 9 . 9 1 9 . 6 0 3}$ \\
2010 & 130.699 .603 .175 & 71.854 .817 .845 & $\mathbf{2 5 . 7 6 0 . 2 5 6 . 0 7 4}$ \\
2011 & 174.054 .555 .700 & 94.337 .347 .025 & $\mathbf{3 3 . 8 3 1 . 9 5 7 . 3 9 5}$ \\
2012 & 239.177 .767 .334 & 125.995 .566 .775 & $\mathbf{4 1 . 2 6 0 . 4 3 2 . 7 6 5}$ \\
2013 & 305.540 .186 .050 & 155.802 .426 .355 & $\mathbf{5 4 . 1 9 9 . 2 8 4 . 1 1 9}$ \\
2014 & 368.501 .011 .900 & 178.042 .856 .980 & $\mathbf{6 4 . 8 9 3 . 7 9 6 . 4 8 4}$ \\
2015 & 430.305 .949 .840 & 200.056 .194 .310 & $\mathbf{7 2 . 6 5 2 . 6 9 8 . 9 6 1}$ \\
2016 & 485.275 .164 .486 & 217.706 .241 .360 & $\mathbf{7 0 . 0 0 2 . 6 5 4 . 7 2 4}$ \\
2017 & 530.850 .073 .871 & 238.364 .356 .355 & $\mathbf{1 1 8 . 8 2 4 . 5 8 2 . 9 2 6}$ \\
2018 & 545.438 .339 .485 & 258.522 .027 .817 & $\mathbf{7 7 . 1 8 4 . 0 4 0 . 7 1 3}$ \\
2019 & $\mathbf{4 9 8 . 4 5 0 . 1 6 7 . 7 2 9}$ & $\mathbf{8 6 . 7 7 5 . 8 1 8 . 3 3 4}$ & $\mathbf{8 3 . 0 9 1 . 4 2 6 . 9 8 3}$ \\
\hline
\end{tabular}

Pada Tabel 4 dapat dianalisis bahwa terjadi perubahan yang fluktuatif pada Jumlah Tabungan Anggota CU dari Tahun 2009-2019. Hal itu dapat diperhatikan pada masing-masing aspek. Pada aspek Cu Khatulitiwa Bakti cenderung terjadi peningkatan dari tahun ke tahun. Sedangkan pada aspek $\mathrm{Cu}$ Bona Ventura juga 
cenderung terjadi peningkatan, meskipun terjadi penurunan pada tahun 2019. Selanjutnya pada aspek $\mathrm{Cu}$ Pancur Dangeri terjadi perubahan yang lebih fluktuatif dari aspek sebelumnya. Hal itu dapat dilihat dari penurunan yang terjadi pada tahun 2014 kemudian meningkat kembali di tiga tahun berikut. Peningkatan tertinggi terjadi pada tahun 2017 diikuti dengan penurunan pada dua tahun selanjutnya.

Tabel 5 <Data Jumlah Anggota CU dari Tahun 2009-2019>

\begin{tabular}{lccc}
\hline Tahun & Cu Khatulitiwa Bakti & Cu Bona Ventura & Cu Pancur Dangeri \\
\hline 2009 & 23.810 & 8.871 & 6.015 \\
2010 & 28.044 & 10.856 & 7.118 \\
2011 & 34.687 & 13.964 & 8.654 \\
2012 & 41.461 & 15.980 & 9.608 \\
2013 & 45.510 & 17.782 & 10.296 \\
2014 & 48.947 & 19.250 & 11.007 \\
2015 & 51.077 & 20.492 & 11.479 \\
2016 & 51.637 & 21.694 & 12.731 \\
2017 & 53.422 & 21.198 & 13.542 \\
2018 & 53.122 & 20.516 & 14.290 \\
2019 & 57.043 & 21.237 & 15.076 \\
\hline
\end{tabular}

Tabel 5 mendeskripsikan mengenai Jumlah Anggota CU dari Tahun 2009-2019. Salah satu faktor yang mempengaruhi kemajuan dari suatu credit union adalah jumlah anggota yang ada di dalam lingkup credit union tersebut (Cahyani, 2015).

Tabel 6 <Data Jumlah Asset CU dari Tahun 2009-2019>

\begin{tabular}{lccc}
\hline Tahun & Cu Khatulitiwa Bakti & Cu Bona Ventura & Cu Pancur Dangeri \\
\hline $\mathbf{2 0 0 9}$ & 111.163 .945 .620 & 60.712 .397 .352 & 29.711 .929 .274 \\
$\mathbf{2 0 1 0}$ & 142.740 .433 .983 & 77.547 .175 .892 & 31.238 .851 .633 \\
$\mathbf{2 0 1 1}$ & 188.667 .698 .782 & 102.578 .827 .278 & 38.546 .567 .137 \\
$\mathbf{2 0 1 2}$ & 257.491 .618 .943 & 138.727 .964 .165 & 50.486 .338 .495 \\
$\mathbf{2 0 1 3}$ & 327.634 .463 .830 & 171.082 .685 .415 & 61.802 .753 .773 \\
$\mathbf{2 0 1 4}$ & 393.471 .531 .818 & 198.714 .264 .612 & 73.812 .945 .140 \\
$\mathbf{2 0 1 5}$ & 528.035 .044 .663 & 224.967 .332 .929 & 79.684 .724 .976 \\
$\mathbf{2 0 1 6}$ & 564.385 .302 .391 & 248.049 .812 .122 & 81.433 .373 .175 \\
$\mathbf{2 0 1 7}$ & 590.598 .881 .585 & 277.639 .253 .894 & 81.728 .303 .552 \\
$\mathbf{2 0 1 8}$ & 616.110 .997 .306 & 295.974 .577 .915 & 89.015 .565 .666 \\
$\mathbf{2 0 1 9}$ & 636.436 .932 .218 & 296.114 .180 .065 & 95.795 .715 .844 \\
\hline
\end{tabular}

Tabel 7 <Data Uji Spesifikasi Model Data Panel 1>

\begin{tabular}{lllllll}
\hline Variabel & \multicolumn{2}{l}{ Fixed effects } & \multicolumn{3}{l}{ Random effects } \\
\hline ln_pinjama $~ 1$ & Coef. & Std. Err & P $>\mathrm{t}$ & Coef. & Std. Err & $\mathrm{P}>\mathrm{t}$ \\
ln_bunga_x1 & -0.533 & 0.181809 & 0.007 & -0.31525 & 0.143265 & 0.028 \\
ln_jumangg $~ 2$ & 0.821 & 0.194654 & 0.000 & 0.480642 & 0.125682 & 0.000 \\
ln_tabunga 3 & 0.238 & 0.096888 & 0.021 & 0.539323 & 0.100426 & 0.000 \\
_cons & 12.693 & 2.229878 & 0.000 & 7.740725 & 1.713223 & 0.000 \\
R-sq: & 0.9609 & & & 0.9701 & & \\
Prob $>$ F & 0.0000 & & & 0.0000 & & \\
\hline
\end{tabular}

\section{Uji hausman}

Keterangan:

Dari uji hausman diperolah H0: Random model dan Ha: Fixed model dengan probabilitas signifikan, maka H0 ditolak dan dipilih fixed effects. Artinya dari uji tersebut dapat diperoleh bahwa perbedaan antar individu dapat diakomodasi dari intersepnya (Basuki, 2019). 


\begin{tabular}{c|cccc} 
& \multicolumn{2}{c}{ Coefficients } & & \\
& $\begin{array}{c}(\mathrm{b}) \\
\text { fixed2 }\end{array}$ & $\begin{array}{c}(\mathrm{B}) \\
\text { random2 }\end{array}$ & $\begin{array}{c}\text { (b-B) } \\
\text { Difference }\end{array}$ & $\begin{array}{c}\text { sqrt(diag(V_b-V_B ) } \\
\text { S.E. }\end{array}$ \\
\hline ln_bunga_x1 & -.533163 & -.3152455 & -.2179175 & .198086 \\
ln_jumangg 2 & .820673 & .4806417 & .3400313 & .2295857 \\
ln_tabunga 3 & .2375533 & .5393225 & -.3017693 & .0829874 \\
\hline
\end{tabular}

$\mathrm{b}=$ consistent under $\mathrm{Ho}$ and $\mathrm{Ha}$; obtained from $\mathrm{xtreg}$ $B=$ inconsistent under $\mathrm{Ha}$, efficient under Ho; obtained from xtreg

Test: Ho: difference in coefficients not systematic

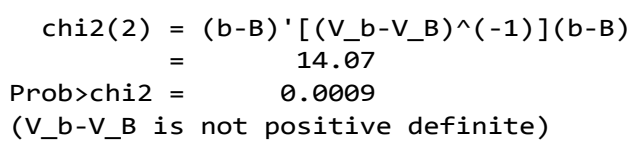

Gambar $1<$ Hasil Uji Hasuman>

\section{Uji Normalitas 1}

Shapiro-Wilk test

Shapiro-Wilk w test for normal data

\begin{tabular}{r|ccccc} 
Variable & Obs & W & V & z & Prob $>z$ \\
\hline error1 & $\begin{array}{c}33 \\
\text { Gambar 2 }\end{array}$ & $\begin{array}{c}0.95407 \\
\text { Hasil Uji Normalitas } 1>\end{array}$
\end{tabular}

Gambar 2 menunjukkan bahwa Ho: error terdistribusi normal dan Ha: error tidak terdistribusi normal. Dari hasil uji normalitas 1 ini didapatkan bahwa probabilitas tidak signifikan, maka error tidak terdistribusi dengan normal. Namun karena jumlah sampel mencukupi, persamaan model tersebut diasumsikan normal (Ghasemi \& Zahediasl, 2012).

\section{Uji Heteroskedastisitas 1}

Uji Heteroskedastisitas dibutuhkan untuk setiap uji regresi. Harapannya adalah tidak ada heteroskedastisitas. Jika terdapat heteroskedastisitas maka perlu dilakukan intervensi.

Uji heteroskedastisitas fixed effects (breush pagan lagrange multiplier)

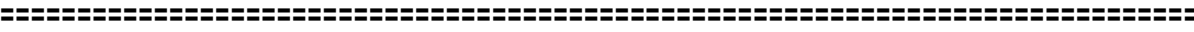

$$
\begin{aligned}
& \text { * Breusch-Pagan Lagrange Multiplier Panel Heteroscedasticity Test }
\end{aligned}
$$

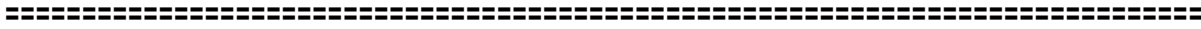

$$
\begin{aligned}
& \text { Ho: Panel Homoscedasticity - Ha: Panel Heteroscedasticity }
\end{aligned}
$$

$\begin{array}{llr}\text { Lagrange Multiplier LM Test } & = & 3.30332 \\ \text { Degrees of Freedom } & = & 2.0 \\ \text { P-Value }>\text { Chi2(2) } & =0.19173\end{array}$

\section{Gambar 3 <Data Hasil Uji Heteroskedastisitas>}


Kesimpulan:

Probabilitas tidak signifikan maka model bersifat homokedastisiti atau tidak ada masalah heterokedastisitas.

\section{Uji Multikolinearitas 1}

Untuk menguji multikolinearitas, kita dapat membandingkan regresi $\mathrm{R}$ kuadrat variabel bebas terhadap variabel terikat dengan regresi kuadrat $\mathrm{R}$ antar variabel bebas. Jika $\mathrm{R} 2$ regresi variabel bebas variabel terikat lebih besar dari R2 regresi antar variabel bebas, maka dapat disimpulkan bahwa model tidak mengandung multikolinearitas, Regresi variable independent terhadap variable dependen. Artinya tidak terbukti ada hubungan yang kuat antara variabel dependen pada penelitian ini. Oleh karena itu penelitian ini bisa dianalisis menggunakan analisis regresi.

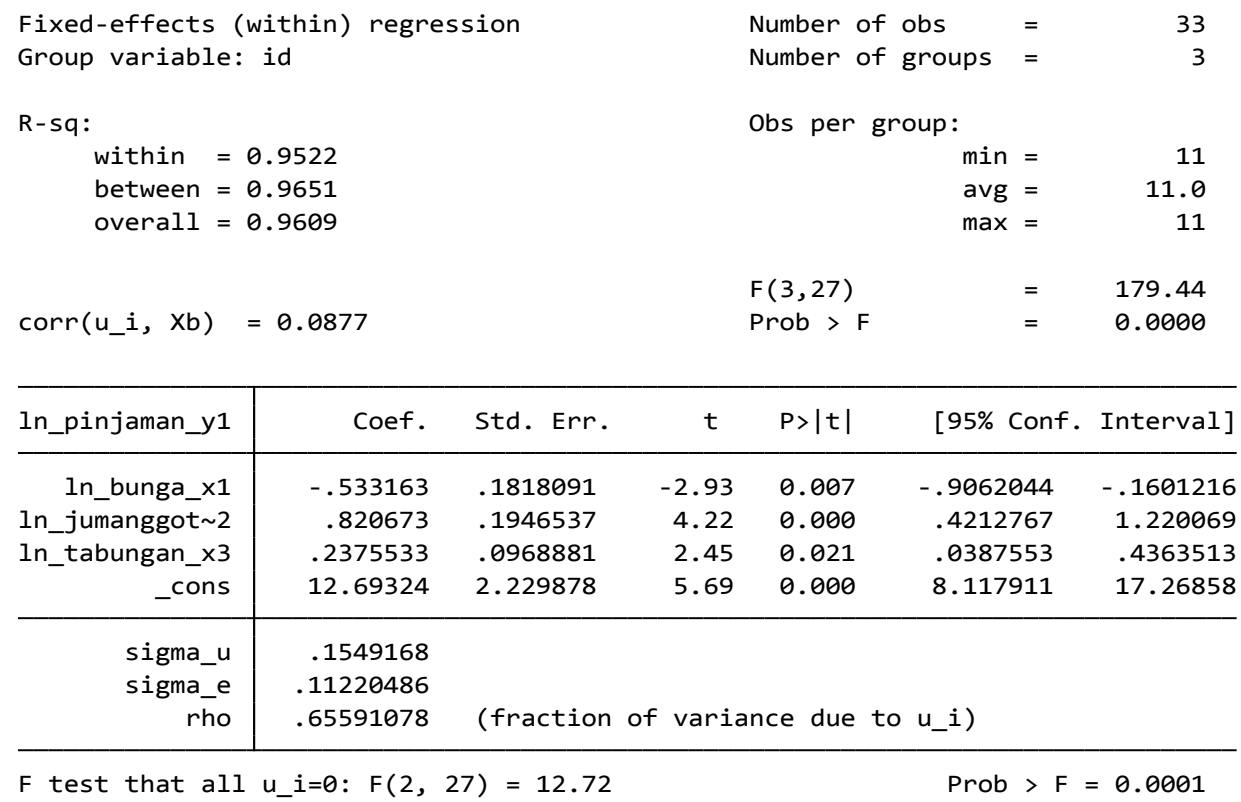

\section{Gambar 4 <Data Hasil Uji Heteroskedastisitas>}

Regresi antar variable independent

Dari hasil uji regresi multikolinearitas antar variabel didapatkan hasil bahwa nilai R0 > R1, R2, R3. Maka model telah terbebas dari isu multikoliniearitas.

Regresi 3. R3=0.905

\section{Gambar 7. Hasil regresi 1}

Tabel $8<$ Hasil Uji Spesifikasi Model Data Panel 2>

\begin{tabular}{lllllll}
\hline Variabel & Fixed effects & \multicolumn{5}{c}{ Random effects } \\
\hline ln_aset_y2 & Coef. & Std. Err & P $>$ t & Coef. & Std. Err & P>t \\
ln_pinjama 1 & 0.812 & 0.120807 & 0 & 1.150622 & 0.10729 & $\mathbf{0}$ \\
ln_bunga_x1 & -0.295 & 0.131048 & 0.033 & -0.11102 & 0.089418 & $\mathbf{0 . 2 1 4}$ \\
ln_jumangg 2 & 0.386 & 0.157352 & 0.021 & -0.09743 & 0.089063 & $\mathbf{0 . 2 7 4}$ \\
ln_tabunga 3 & -0.059 & 0.06725 & 0.388 & -0.02297 & 0.081945 & $\mathbf{0 . 7 7 9}$ \\
_cons & 3.567 & 2.07623 & 0.098 & -1.68906 & 1.292106 & $\mathbf{0 . 1 9 1}$ \\
R-sq: & 0.9831 & & & 0.9917 & & \\
Prob $>$ F & 0.0000 & & & 0.0000 & & \\
\hline
\end{tabular}




\section{Uji hausman}

\begin{tabular}{r|rrrr}
\cline { 2 - 4 } & $\begin{array}{c}(\mathrm{b}) \\
\text { fixed3 }\end{array}$ & $\begin{array}{c}(\mathrm{B}) \\
\text { random3 }\end{array}$ & $\begin{array}{c}(\mathrm{b}-\mathrm{B}) \\
\text { Difference }\end{array}$ & $\begin{array}{c}\text { sqrt (diag(V_b-V_B })) \\
\text { S.E. }\end{array}$ \\
\hline In_pinjama 1 & .812249 & 1.150622 & -.3383727 & .1041281 \\
In_bunga_x1 & -.2950634 & -.1110178 & -.1840455 & .1353102 \\
In_jumangg 2 & .3855531 & -.0974309 & .482984 & .1731809 \\
ln_tabunga 3 & -.0590088 & -.0229748 & -.036034 & .0145685 \\
\hline
\end{tabular}

$\mathrm{b}=$ consistent under $\mathrm{Ho}$ and $\mathrm{Ha}$; obtained from xtreg

$\mathrm{B}=$ inconsistent under $\mathrm{Ha}$, efficient under Ho; obtained from xtreg

Test: Ho: difference in coefficients not systematic

$$
\begin{array}{rlrl}
\operatorname{chi2}(2) & = & (b-B)^{\prime}\left[\left(V_{-} b-V_{-} B\right)^{\wedge}(-1)\right](b-B) \\
& = & 11.03 \\
\text { Prob>chi2 } & = & 0.0040 \\
\left(V_{-} b-V_{-} B\right. & \text { is } & \text { not } & \text { positive definite })
\end{array}
$$

Simpulan:

\section{Gambar $8<$ Uji Hausman $>$}

H0: Random model

Ha: Fixed model

Probabilitas signifikan, maka $\mathrm{H} 0$ ditolak dan dipilih fixed effects.

Uji Normalitas 2

Shapiro-Wilk test Shapiro-Wilk W test for normal data

\begin{tabular}{r|rcccr} 
Variable & Obs & W & V & z & Prob >z \\
\hline error2 & 33 & 0.96234 & 1.286 & 0.523 & 0.30056
\end{tabular}

Ho: error terdistribusi normal

\section{Gambar $9<$ Uji Normalitas 2>}

Ha: error tidak terdistribusi normal

- Kesimpulan: probabilitas tidak signifikan, maka error tidak terdistribusi dengan normal.

- Namun karena jumlah sampel mencukupi, persamaan model tersebut diasumsikan normal

- (Ghasemi \& Zahedias1, 2012)

\section{Uji Heteroskedastisitas 2}

Uji Heteroskedastisitas dibutuhkan untuk setiap uji regresi. Harapannya adalah tidak ada heteroskedastisitas. Jika terdapat heteroskedastisitas maka perlu dilakukan intervensi.

Uji heteroskedastisitas fixed effects (breush pagan lagrange multiplier)

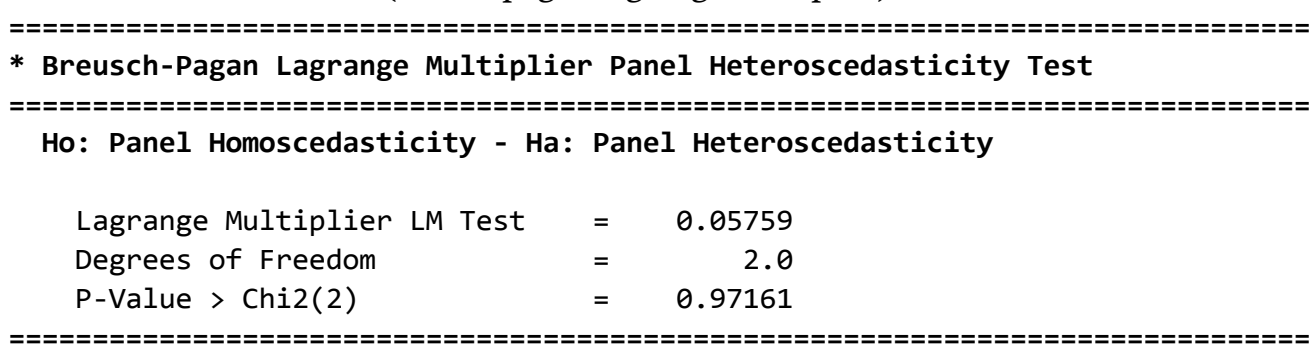

Gambar $10<$ Uji Heteroskedastisitas 2> 
Probabilitas tidak signifikan maka model bersifat homokedastisiti atau tidak ada masalah heterokedastisitas.

\section{Uji Multikolinearitas 2}

Untuk menguji multikolinearitas, kita dapat membandingkan regresi $\mathrm{R}$ kuadrat variabel bebas terhadap variabel terikat dengan regresi kuadrat $\mathrm{R}$ antar variabel bebas. Jika $\mathrm{R} 2$ regresi variabel bebas variabel terikat lebih besar dari R2 regresi antar variabel bebas, maka dapat disimpulkan bahwa model tidak mengandung multikolinearitas.

Regresi variable independent terhadap variable dependen

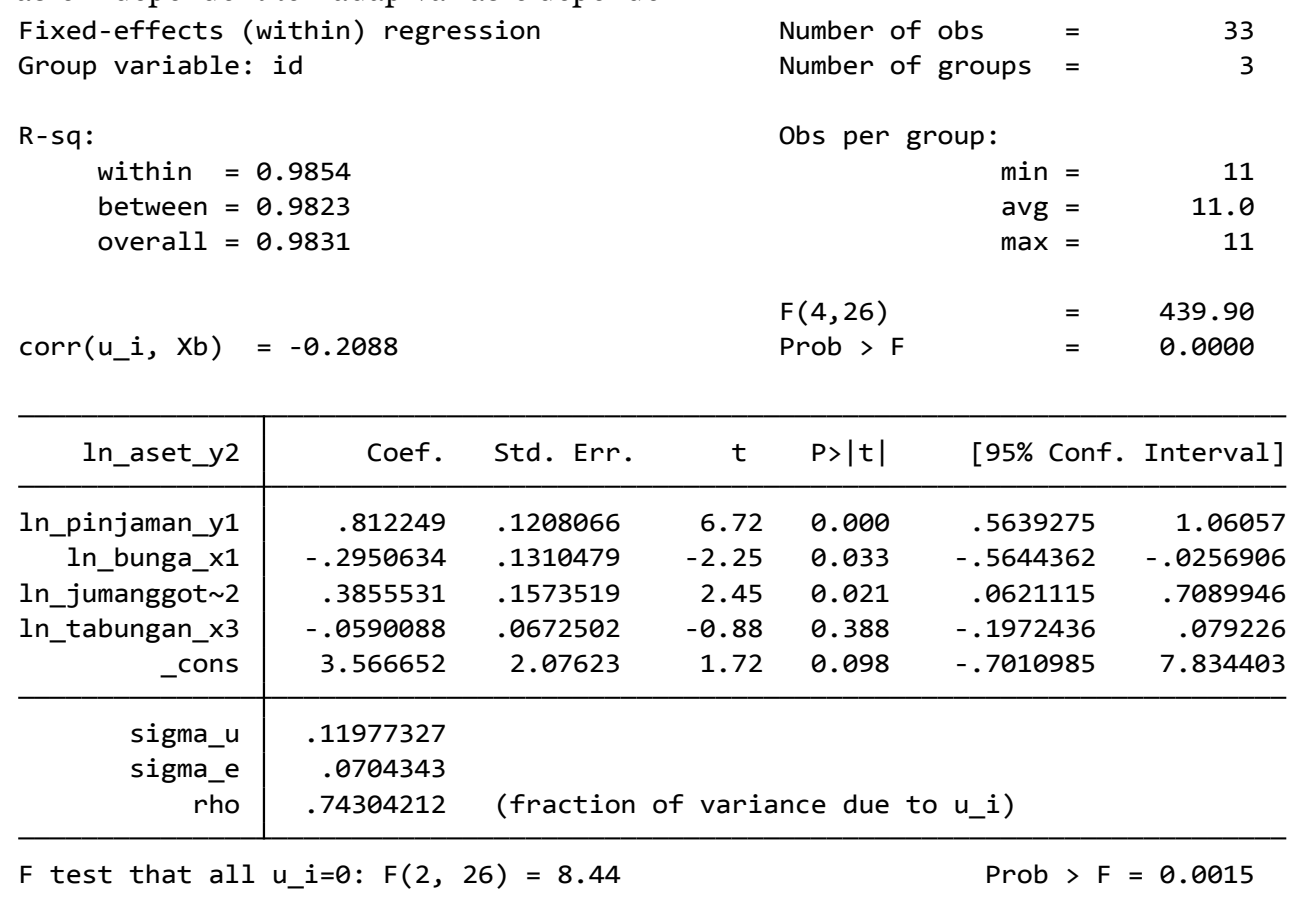

Gambar $11<$ Uji Hausman>

Regresi antar variable independent

Regresi 1. R1 $=0.96$

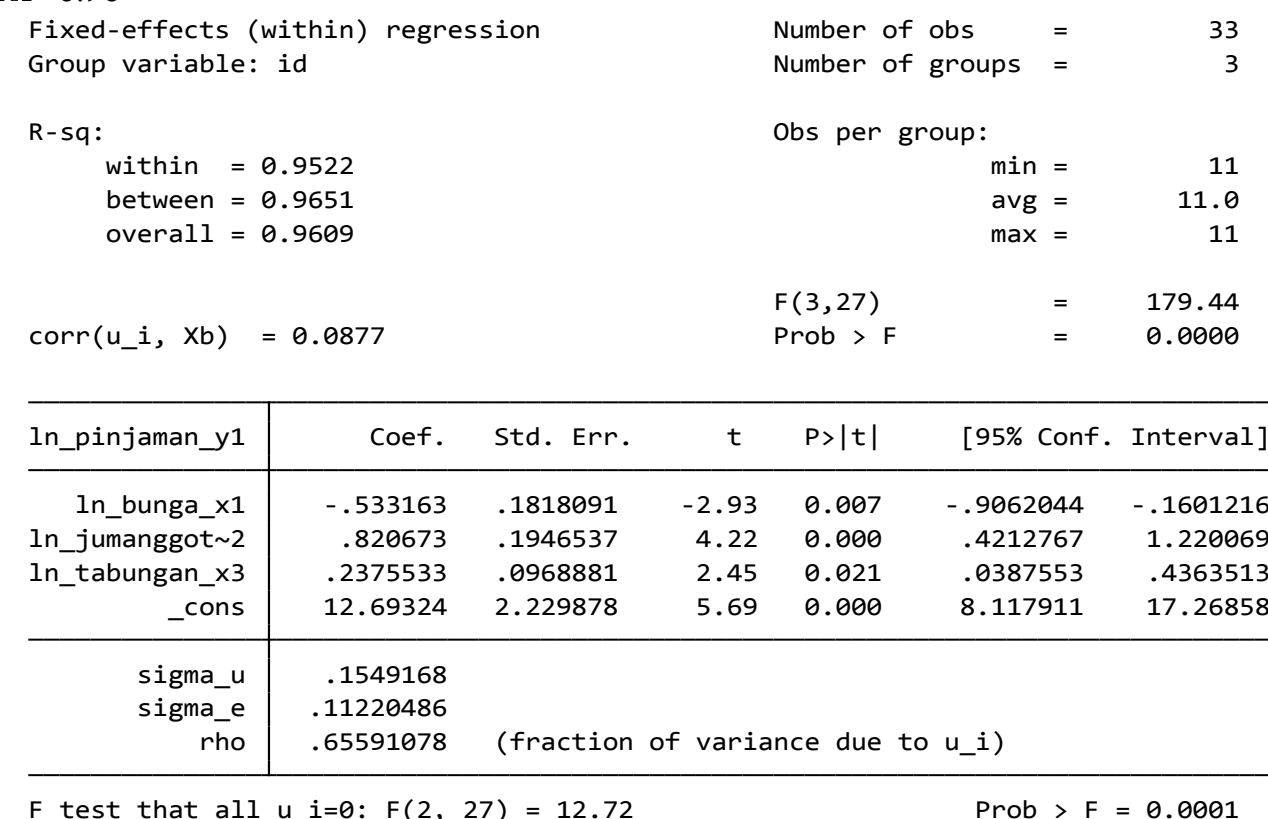

Gambar $12<$ Uji Hausman> 
Selanjutnya didapatkan nilai 1) Regresi2. R2=0.29, 2) Regresi3. R3=0.91, dan 3) Regresi4. R4=0.94

Kesimpulan:

Nilai R0 > R1, R2, R3. Maka model telah terbebas dari isu multikoliniearitas. Sama halnya dengan uji multikolinearitas yang pertama, dari uji yang sudah dilakukan diperoleh bahwa tidak ada keterkaitan yang signifikan diantara variabel bebas.

\section{Path analysis 1}

Tabel $9<$ Hasil uji pengaruh Tidak Langsung $>$

\begin{tabular}{|c|c|c|c|c|c|c|}
\hline Variabel & Coef. & STD. ERR & $T$ & $\mathbf{P}>\mathrm{T}$ & \multicolumn{2}{|c|}{ [95\% Conf. Interval] } \\
\hline $\mathrm{X} 1 \rightarrow \mathrm{Y} 1 \rightarrow \mathrm{Y} 2$ & -0.533163 & 0.181809 & 2.93 & 0.007 & -0.9062 & -0.16012 \\
\hline $\mathrm{X} 2 \rightarrow \mathrm{Y} 1 \rightarrow \mathrm{Y} 2$ & 0.820673 & 0.194654 & 4.22 & 0.000 & 0.421277 & 1.220069 \\
\hline $\mathrm{X} 3 \rightarrow \mathrm{Y} 1 \rightarrow \mathrm{Y} 2$ & 0.2375533 & 0.096888 & 2.45 & 0.021 & 0.038755 & 0.436351 \\
\hline $\mathrm{Y} 1 \rightarrow \mathrm{Y} 2$ & 0.812249 & 0.120807 & 6.72 & 0.000 & 0.563928 & 1.06057 \\
\hline
\end{tabular}

Dari tabel 9 dapat diperoleh informasi bahwa variable x1 x2 x3 dan Y1 memiliki pengaruh signifikan terhadap Y2 secara langsung karena $\mathrm{p}$ value $<0.05$. Artinya setiap terjadi kenaikan $\mathrm{x} 1$ sebesar $1 \%$ maka akan berpengaruh secara langsung pada penurunan Y1 sebesar $0.5 \%$ (karena sudah di log-kan).

\section{Sobel Test}

Sobel test merupakan uji untuk mengetahui apakah hubungan yang melalui sebuah variabel mediasi secara signifikan mampu sebagai mediator dalam hubungan tersebut (Koopman, Howe, \& Hollenbeck, 2014; Preacher \& Leonardelli, 2001). Hasil perhitungan sobel test menunjukkan nilai z sebesar 20.27381 (abaikan tanda positif atau negatif) atau lebih besar dari 1,96 (abaikan tanda positif atau negatif) dengan taraf sig. 5\% maka dapat dikatakan Y1 dapat menjadi mediasi dari variable X1 terhadap X2. Atau dengan kata lain terjadi hubungan signifikan secara tidak langsung antara X1 dan X2 dengan mediasi Y1.

Gambaran jalur

Catatan

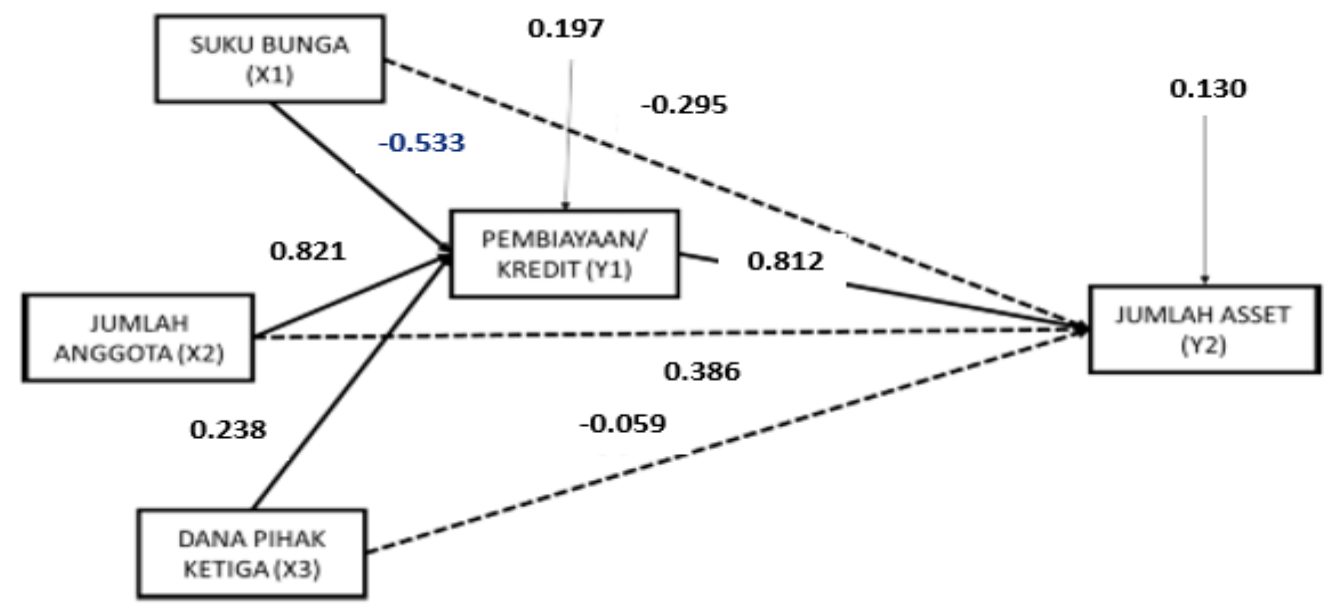

Gambar $13<$ Rumus e1 dan e2 dapat dicari dengan formula $\square=(1-\mathrm{R} 2) 1 / 2>$

Tabel $10<$ Hasil Uji Pengaruh Langsung $>$

\begin{tabular}{lccccc}
\hline Variabel & Coef. & Std. Err & Axb & Sab & Z \\
\hline $\mathrm{X} 1 \rightarrow$ Y2 & -0.295 & 0.131048 & 0.157317 & 0.00776 & 20.27381 \\
$\mathrm{X} 2 \rightarrow$ Y2 & 0.386 & 0.157352 & 0.316413 & 0.022308 & 14.18377 \\
$\mathrm{X} 3 \rightarrow$ Y2 & -0.059 & 0.06725 & -0.01402 & 0.000288 & -48.689 \\
\hline
\end{tabular}


Dari gambar 5 dan tabel 10 dapat diperoleh hasil bahwa variable X1, X2, X3, dan Y1 mempengaruhi Y2 secara langsung dan signifikan. Selanjutnya variable X1 dan X2 mempengaruhi Y2 secara tidak langsung dan signifikan dengan bantuan mediasi dari Y1

\section{Pembahasan}

Dari hasil penelitian menunjukan hubungan tidak langsung dan signifikan antara Perubahan Tingkat Bunga kredit terhadap Asset melalui Pembiayaan dengan nilai koofisien sebesar -0,53 persen, yang berarti apabila terjadi kenaikan tingkat suku bunga 1 persen maka akan menurunkan jumlah Pembiayaan sebesar -0,53 persen (Adnan, Ridwan, \& Fildzah, 2016; Oka, Purnamawati, \& Sinarwati, 2015). Selanjutnya hasil penelitian ini juga menunjukan hubungan langsung dan signifikan antara perubahan Tingkat Bunga kredit terhadap jumlah Asset dengan nilai koofisien sebesar -0,295 persen, yang berarti apabila terjadi kenaikan tingkat suku bunga 1 persen maka akan menurunkan jumlah Asset sebesar -0,295 persen (Disemadi, 2019). Kopdit credit union dalam memperbaiki kehidupan dan mengangkat masyarakat dari jurang kemiskinan untuk menjadi lebih sejahtera (Putra \& Haryaningsih, 2021). Kopdit credit union dapat menjadi solusi dalam mengurangi kemiskinan, dan meningkatkan kapasitas usaha kecil dan usaha mikro.

Kemudian dari hasil penelitian menunjukan hubungan tidak langsung dan signifikan antara Jumlah Anggota terhadap Asset melalui Pembiayaan kredit dengan nilai koofisien sebesar 0,821 persen, yang berarti apabila terjadi kenaikan jumlah anggota sebesar 1 persen maka akan meningkatkan jumlah pembiayaan/kredit sebesar 0,821 persen. Hal ini sejalan dengan penelitian yang dilakukan oleh beberapa peneliti yang menyatakan bahwa terdapat hubungan antara kedua variabel tersebut (Baquié et al., 2021; Supitriyani, Azwar, Susanti, \& Astuti, 2021). Dari hasil penelitian juga menunjukan adanya hubungan langsung dan signifikan antara Jumlah Anggota terhadap jumlah asset dengan nilai koefisien sebesar 0,386 persen yang berarti apabila terjadi kenaikan 1 persen terhadap jumlah anggota akan menaikkan jumlah asset sebesar 0,386 persen. Hal ini didukung oleh penelitian yang dilakukan oleh Ibrahim dan Branne adanya hubungan antara keduanya dan juga beberapa riset lainnya

Lebih lanjut dari hasil penelitian menunjukan hubungan tidak langsung dan signifikan antara Dana Pihak Ketiga terhadap Asset melalui Pembiayaan dengan nilai koofisien sebesar 0,238 persen, yang berarti apabila terjadi kenaikan Dana Pihak Ketiga sebesar 1 persen maka akan meningkatkan jumlah pembiayaan/kredit sebesar 0,238 persen. Hal ini sejalan dengan penelitian yang dilakukan sebelumnya (Dewi \& Zakaria, 2021; Singh, 2021; Swandewi \& Purnawati, 2021) Dari hasil penelitian juga menunjukan hubungan langsung dan tidak signifikan antara Dana Pihak Ketiga terhadap jumlah asset. Dan ini juga seja;an dengan penelitian yang dilakukan beberapa peneliti (Sawitri, 2018; Shahzadi, Malik, Shabbir, \& Yasmind, 2021) Dari hasil penelitian menunjukan hubungan tidak langsung antara Pengaruh Tingkat Suku Bunga, Jumlah Anggota dan Dana Pihak Ketiga terhadap jumlah asset melalui Pembiayaan Kredit secara simultan dengan nilai koofisien sebesar 0,812 persen yang berarti apabila terjadi kenaikan 1 persen terhadap Pembiayaan Kredit akan meningkatkan jumlah asset sebesar 0,812 persen. Kondisi ini menjadikan ketiga variabel tersebut berhubungan dengan aset dan hal ini sesuai dengan apa yang dilakukan oleh peneliti sebelumnya (Septiawan, 2020)

\section{Simpulan}

Sebagai simpulan dari penelitian ini adalah adanya hubungan tidak langsung dan signifikan antara Perubahan Tingkat Bunga kredit terhadap Asset melalui Pembiayaan. Selain itu dari hasil penelitian juga diperoleh beberapa simpulan lainnya yaitu, 1) adanya hubungan langsung dan signifikan antara perubahan Tingkat Bunga kredit terhadap jumlah Asset, 2) Kemudian terjadi hubungan tidak langsung dan signifikan antara Jumlah Anggota terhadap Asset melalui Pembiayaan kredit, 3) adanya hubungan langsung dan signifikan antara Jumlah Anggota terhadap jumlah asset, 4) adanya hubungan tidak langsung dan signifikan antara Dana Pihak Ketiga terhadap Asset melalui Pembiayaan, 5) adanya hubungan langsung dan tidak signifikan antara Dana Pihak Ketiga terhadap jumlah asset dan 6) adanya hubungan tidak langsung antara Pengaruh Tingkat Suku Bunga, Jumlah Anggota dan Dana Pihak Ketiga terhadap jumlah asset melalui Pembiayaan Kredit secara simultan.

\section{Referensi}

Adnan, A., Ridwan, R., \& Fildzah, F. (2016). Pengaruh Ukuran Bank, Dana Pihak Ketiga, Capital Adequacy Ratio, dan Loan To Deposit Ratio Terhadap Penyaluran Kredit Pada Perusahaan Perbankan yang Terdaftar Di Bursa Efek Indonesia Tahun 2011-2015. Jurnal Dinamika Akuntansi Dan Bisnis, 3(2), 49-64. 
Ahmadsyah, I., Rahmati, R., \& Aufa, S. (2019). Analisis Pengaruh Pembiayaan Modal Kerja, Pembiayaan Investasi, Dan Pembiayaan Konsumtif Terhadap Total Aset Bank Aceh Periode 2016-2019. Jurnal Ekonomi Regional Unimal, 2(3), 152-160.

Anam, M. K., \& Khairunnisah, I. F. (2019). Pengaruh pembiayaan bagi hasil dan financing to deposit ratio (FDR) terhadap profitabilitas (ROA) Bank Syariah Mandiri. Zhafir| Journal of Islamic Economics, Finance, and Banking, 1(2), 99-118.

Baquié, S., Urpelainen, J., Khanwilkar, S., Galletti, C. S., Velho, N., Mondal, P., . . DeFries, R. (2021). Migration, assets, and forest degradation in a tropical deciduous forest of South Asia. Ecological Economics, 181, 106887.

Basuki, A. T. (2019). Panel Data Regression Teaching Materials. Retrieved from https://ekonometrikblog.files.wordpress.com/2019/09/panel-data-regression.pdf.

Beni, S. Ebook Credit Union Sebagai Sarana Meningkatkan Kesejahteraan Masyarakat.

Beni, S., Rano, G., \& Tipo, C. U. L. (2017). Credit Union sebagai penggerak ekonomi masyarakat dayak Kalimantan Barat. Pros. Int. Congr. I Dayak Cult, 1, 168-177.

Cahyani, M. T. (2015). Pengaruh Jumlah Anggota Terhadap Perolehan Sebagai Variabel Intervening Pada Koperasi Simpan Pinjam Wisuda Guna Raharja Denpasar Tahun 2012-2014. Jurusan Pendidikan Ekonomi (JJPE), 5(1), 1-10.

Data. (2021). Perkembangan Rata-rata Tingkat Bunga Simpanan dan Tingkat Bunga Pembiayaan/Kredit pada Kopdit Credit Union di Kalimantan Barat dari Tahun 2009 - 2019.

Dewi, F. C., \& Zakaria, H. M. (2021). Pengaruh Dana Pihak Ketiga Dan LDR Terhadap ROA Pada Perbankan. Jurnal Ilmu Keuangan Dan Perbankan (JIKA), 10(2).

Disemadi, H. S. (2019). Risk Management In The Provision Of People's Business Credit As Implementation Of Prudential Principles. Diponegoro Law Review, 4(2), 194-208.

Diskopukm (Producer). (2020). Kunjungan Kepala Dinas Koperasi, dan UKM Provinsi Kalbar ke Puskopdit BKCU Kalimantan. Retrieved from https://diskopukm.kalbarprov.go.id/kunjungan-kepala-dinas-koperasi-danukm-provinsi-kalbar-ke-puskopdit-bkcu-kalimantan/

Ghasemi, A., \& Zahediasl, S. (2012). Normality tests for statistical analysis: a guide for non-statisticians. International journal of endocrinology and metabolism, 10(2), 486.

Gustifa, R. (2013). Faktor-Faktor Yang Mempengaruhi Kredit Macet Pada Koperasi Simpan Pinjam Di Kota Padang (Didasarkan Persepsi Anggota Koperasi). Manajemen S-1, 1(1).

Hakim, F. K., \& Hasanah, M. (2020). Pengaruh Pembiayaan Mudharabah dan Musyarakah Terhadap Return On Asset BPRS di Indonesia. Jurnal Ekonomi, 25(1), 132-146.

Hakim, L., Sabil, S., Lestiningsih, A. S., \& Widodo, D. P. (2019). Pengaruh Pemungutan Pajak Pertambahan Nilai terhadap Laporan Keuangan. Jurnal SIKAP (Sistem Informasi, Keuangan, Auditing Dan Perpajakan), 4(1), $1-11$.

Hutasoit, D. J. (2019). Analisis Laporan Keuangan pada Credit Union (CU)(Studi Kasus: Pada Credit Union (CU) Abadi Ajibata Kabupaten Toba Samosir).

Khosmas, F. Ekonomi Kerakyatan Baru (Gerakan Credit Union di Kalimantan Barat). Guru Membangun, 25(3).

Koopman, J., Howe, M., \& Hollenbeck, J. R. (2014). Pulling the Sobel test up by its bootstraps More statistical and methodological myths and urban legends (pp. 234-254): Routledge.

Maran. (2021). Pengaruh Faktor Internal dan Eksternal terhadap Simpanan, Pinjaman dan Aset Pada Kopdit Credit Union di Kalimantan Barat.

Oka, K. W. L., Purnamawati, I. G. A., \& Sinarwati, N. K. (2015). Pengaruh Dana Pihak Ketiga, Penilaian 5C Kredit, Dan Kualitas Kredit Terhadap Keputusan Pemberian Kredit Di PT. Bank Pembangunan Daerah Bali Cabang Singaraja. JIMAT (Jurnal Ilmiah Mahasiswa Akuntansi) Undiksha, 3(1).

Preacher, K. J., \& Leonardelli, G. J. (2001). Calculation for the Sobel test. Retrieved January, 20, 2009.

Putra, W., \& Haryaningsih, S. (2021). Pengaruh perubahan kebijakan suku bunga, jumlah anggota, dan dana pihak ketiga terhadap asset perusahaan melalui pembiayaan kredit. JPPI (Jurnal Penelitian Pendidikan Indonesia), 7(2), 292-305.

Ratnasari, E. (2014). Upaya Manager Pada Credit Union Dalam Menanggulangi Kredit Macet. FOKUS: Publikasi Ilmiah untuk Mahasiswa, Staf Pengajar dan Alumni Universitas Kapuas Sintang, 14(2).

Sawitri, N. N. (2018). The prediction of third party funds, interest rates, and non-performing loans toward loan to deposit ratios and its impact on return on assets on commercial banks in Indonesia. Jurnal Manajemen, 22(3), 409-420.

Septiawan, R. (2020). Pengaruh Dana Pihak Ketiga, BI Rate, Dan Kurs Valuta Asing Terhadap Rasio PErtumbuhan Aset Bank Syariah Mandiri Di Indonesia Periode 2015-2017. UIN Raden Intan Lampung.

Shahzadi, K., Malik, H., Shabbir, M. S., \& Yasmind, A. (2021). Factors affecting profit distribution management of Islamic banks: moderating role of corporate governance. Islamic Banking and Finance Review, 8(1), 78102. 
Singh, A. (2021). Investigating the dynamic relationship between litigation funding, gold, bitcoin and the stock market: The case of Australia. Economic Modelling, 97, 45-57.

Supitriyani, S., Azwar, K., Susanti, E., \& Astuti, A. (2021). Pengaruh Modal Sendiri, Jumlah Anggota Terhadap Pertumbuhan Koperasi Di Kota Pematangsiantar. Jurnal Akuntansi dan Pajak, 21(2).

Swandewi, N. K. M., \& Purnawati, N. K. (2021). Capital Adequacy Ratio Mediates the Effect of Non-Performing Loan on Returns on Assets in Public Commercial Banks. American Journal of Humanities and Social Sciences Research (AJHSSR), 5(1), 651-656. 